\title{
Asymmetric Synthesis of $\alpha$-Methylglutamic Acid and $\alpha$-Methylornithine by a Chiral Isocyano Amide Reagent
}

\author{
Yoshihiro Yamamoto, Mitsunori Kirihata, Itsuo Ichimoto \\ and Hiroo UEDA \\ Department of Agricultual Chemistry, College of Agriculture, \\ University of Osaka Prefecture, Sakai, Osaka 591, Japan
}

Received November 9, 1984

\begin{abstract}
An efficient approach to the asymmetric syntheses of $\alpha$-methylglutamic acid and $\alpha$-methylornithine is described. Two chiral reagents, $\left(2^{\prime} S\right)-N-\left(2^{\prime}\right.$-methoxymethylpyrrolidine)-2-isocyanopropionamide 4 and $\left(2^{\prime} S\right)-N$-( $2^{\prime}$-hydroxymethylpyrrolidine)-2-isocyanopropionamide 5 , were employed for the asymmetric induction. $\alpha$-Methylglutamic acid 7 was synthesized by the asymmetric Michael-addition of methyl acrylate to $\mathbf{4}$ and $\mathbf{5}$ as the key step. The optical yield of $\mathbf{7}$ was $10 \sim 45 \%$ (R-form). $\alpha$-Methylornithine 12 was also synthesized by the reaction of 4 with acrylonitrile as the key step. The optical yield of $\mathbf{1 2}$ was $31.7 \%$ ( $R$-form).
\end{abstract}

$\alpha$-Alkyl amino acids are of biochemical interest because of their properties as enzyme inhibitors. In the previous paper, ${ }^{1,2)}$ we have reported the asymmetric synthesis of $\alpha$-methylornithine 12, a potent competitive inhibitor of ornithine decarboxylase, involving the diastereoselective Michael-addition of acrylonitrile to $(+)$ - and (-)-menthyl $\alpha$-isocyanopropionate; however, the optical yields of $(-)-12$ and $(+)-12$ thus obtained were only 4.7 and $5.8 \%$ respectively.

Subsequently, although several synthetic methods for $\mathbf{1 2}^{3 \sim 5 \text { ) }}$ have been reported, investigations concerning the asymmetric synthesis of $\mathbf{1 2}$ and $\alpha$-methylglutamic acid $\mathbf{7}$ have not been successful.
In recent years, successful syntheses of the chiral ketone, aldehyde, $\alpha$-alkyl amino acid and dipeptide employing $(S)-(-)$-proline derivatives as a chiral auxiliary reagent have been reported as follows: (1) asymmetric induction of methyl vinyl ketone to the chiral enamine $\mathbf{A}^{6)}{ }^{6}$ (2) asymmetric alkylation (benzylation) of the chiral amidine ether $\mathbf{B},{ }^{7)}$ hydrazone $\mathbf{C}^{8,9)}$ and allylamide $\mathbf{D},{ }^{10)}$ (3) asymmetric synthesis of L,D-dipeptide via the chiral intermediate E. ${ }^{11)}$ Sonnet et al. ${ }^{12)}$ reported more recently that diastereoselective metalation and alkylation of the chiral amides $\mathbf{F}$ derived from $(S)$ $(-)$-prolinol and its methyl ether afforded $\alpha$ alkyl amines $\mathbf{F}^{\prime}$ in $12 \sim 82 \%$ e.e.

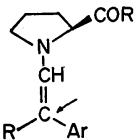

A

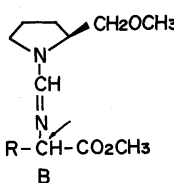

B

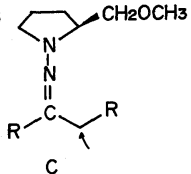

C

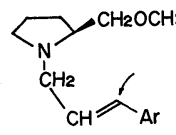

D

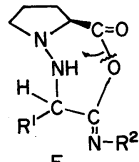

E

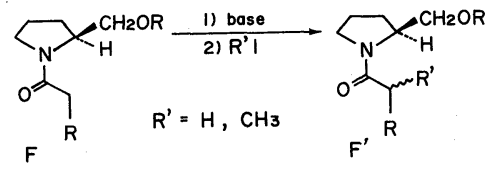


The $S$ configuration induced by $(S)-(-)$ prolinol was opposite to that induced by its methyl ether. According to the new technique for asymmetric induction, they ${ }^{13)}$ succeeded in obtaining both enantiomers of 10-methyl-1dodecanol acetate, the sex pheromone complex of the smaller tea tortrix moth (Adoxophyes sp.), in $74 \%(R)$ or $80 \%(S)$ e.e.

The present paper deals with the asymmetric synthesis of 7 and 12 by using $\left(2^{\prime} S\right)-N-\left(2^{\prime}\right.$ methoxymethylpyrrolidine)-2-isocyanopropionamide 4 and (2'S)- $N$-(2'-hydroxymethylpyrrolidine)-2-isocyanopropionamide 5 as the chiral auxiliary reagents. The amide 4 was prepared by the reaction of $(S)-(-)$ prolinol methyl ether $\mathbf{1 b}$ with methyl isocyanoacetate $\mathbf{2 a}$, and followed by Cmethylation with methyl iodide.

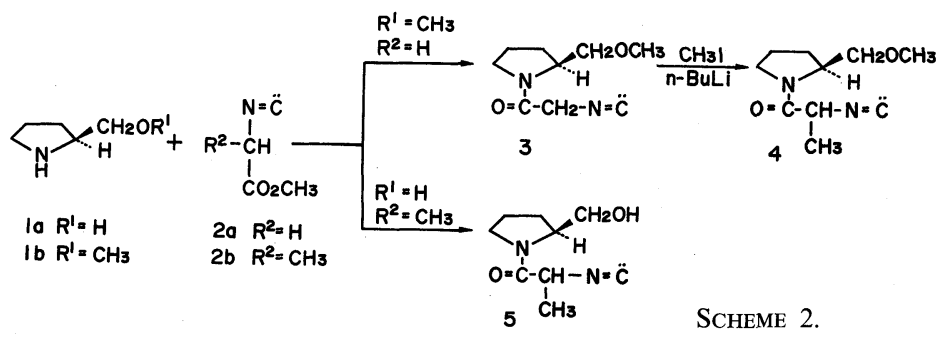

The amide 5 was prepared from $(S)-(-)$ prolinol 1a and methyl 2-isocyanopropionate 2b. The Michael-addition of an equimolar amount of 4 to methyl acrylate in the presence of sodium hydride, and followed by treatment with acetic acid gave $(R)-(-)-7\left([\alpha]_{\mathrm{D}}-1.22^{\circ}\right.$, $10 \%$ e.e.) in a $42 \%$ chemical yield. On the other hand, the amide 5 was treated with 1.6 equimolar amounts of methyl acrylate in the pres-

ence of 1 equimolar amount of sodium hydride, and followed by treatment with acetic acid to give a mixture consisting of $53 \%$ of C,O-dialkyl amide 9 and $23 \%$ of C-alkyl amide 8.

Acid hydrolysis of 9 and 8 with $2 \mathrm{~N}-\mathrm{HCl}$ gave $(S)-(+)-7\left([\alpha]_{\mathrm{D}}+0.61^{\circ}, 5 \%\right.$ e.e. $)$ and $(R)-(-)-7\left([\alpha]_{\mathrm{D}}-5.35^{\circ}, 44 \%\right.$ e.e. $)$ respectively.
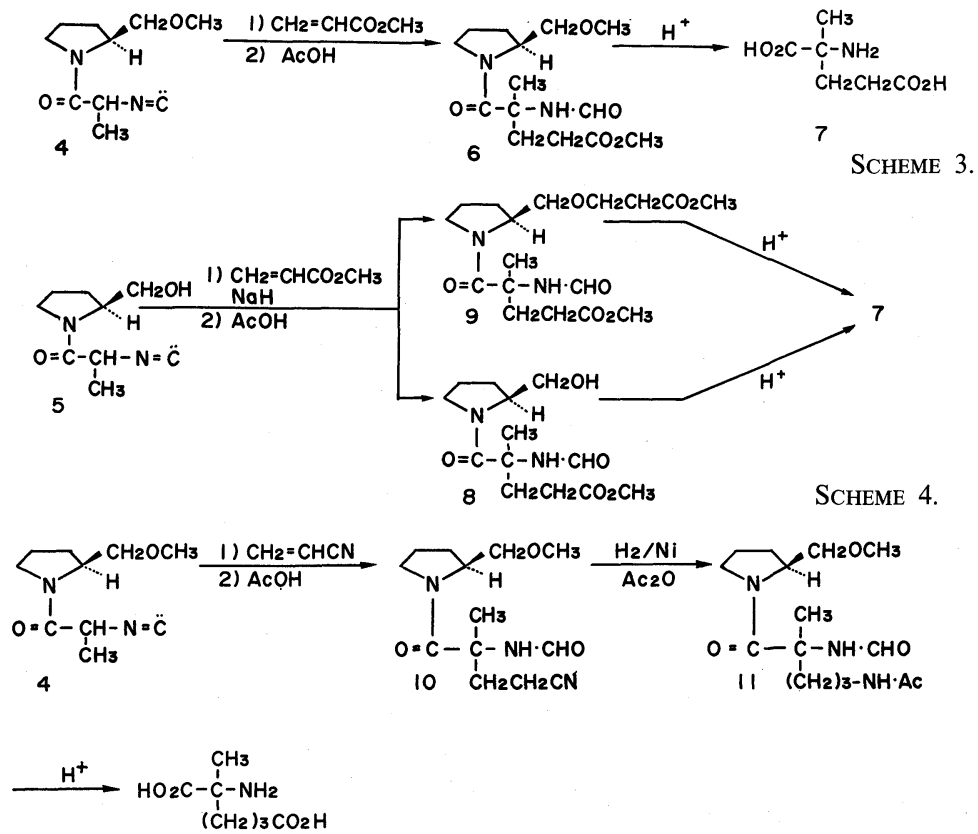
In agreement with the investigation result described by Sonnet et al., ${ }^{12)}$ the configuration of 7 induced by the $(S)$-(-)-prolinol alkyl ether was reversed from $R$ to $S$ as the size of the O-alkyl substituent becomes larger $\left(\mathrm{H} \rightarrow \mathrm{CH}_{3} \rightarrow \mathrm{CH}_{2} \mathrm{CH}_{2} \mathrm{CO}_{2} \mathrm{CH}_{3}\right)$.

Finally, 12 was synthesized in a manner similar to that already described. In this experiment, the amide 4 was employed as a chiral auxiliary reagent, because it gave a more favorable result for the Michael reaction than did 5. The amide 4 was treated with a 1.2 equimolar amount of acrylonitrile, and followed by treatment with acetic acid in a similar manner to Scheme 3. The obtained $\mathbf{1 0}$ was hydrogenated over Raney Nickel catalyst in acetic anhydride to yield 11 . The acid hydrolysis of 11 with $6 \mathrm{~N}-\mathrm{HCl}$ gave $(R)-(-)-12-$ $\mathrm{HCl}\left([\alpha]_{\mathrm{D}}-3.33^{\circ}, 32 \%\right.$ e.e. $)$ in a $28 \%$ overall yield from 4.

\section{EXPERIMENTAL}

Infrared spectra were taken with a JASCO IRA-2 spectrometer, and NMR spectra were recorded with JEOL JNM-MN60 spectrometer. Melting points were determined on Yanaco MP-S3 melting point apparatus and are uncorrected. Optical rotations were measured on a JASCO DIP-SL polarimeter.

(S)-N-(2-Methoxymethylpyrrolidine)-isocyanoacetamide 3. To a solution of the methyl isocyanoacetate $2 \mathrm{a}(3 \mathrm{~g}$, $30.3 \mathrm{mmol})$ in $\mathrm{MeOH}(10 \mathrm{ml})$ was added a solution of the prolinole methyl ether $\mathbf{1 b}(6.2 \mathrm{~g}, 53.9 \mathrm{mmol})$ in $\mathrm{MeOH}$ $(5 \mathrm{ml})$, the mixture being stirred for $24 \mathrm{hr}$ at ambient temperature. After removing the solvent, the residue was purified by silica gel column chromatography (eluting with an increasing amount of AcOEt in benzene) to afford 3 $(4.69 \mathrm{~g}, 85 \%$ from $2 \mathrm{a}), \mathrm{mp} 52^{\circ} \mathrm{C}$. $[\alpha]_{\mathrm{D}}^{25}-79.56^{\circ}(c=0.675$, EtOH). IR $v_{\max }^{\mathrm{KBr}} \mathrm{cm}^{-1}: 2150(\mathrm{~N}=\mathrm{C}:), 1660(\mathrm{C}=\mathrm{O}) .{ }^{1} \mathrm{H}-$ NMR $\left(\mathrm{CDCl}_{3}\right) \delta: 1.68 \sim 2.34(4 \mathrm{H}, \mathrm{m}), 3.14(3 \mathrm{H}, \mathrm{s}, \mathrm{O}-$ $\mathrm{CH}_{3}$ ). Anal. Found: C, 59.26; H, 7.76; N, 15.32. Calcd. for $\mathrm{C}_{9} \mathrm{H}_{14} \mathrm{O}_{2} \mathrm{~N}_{2}$ : C, 59.32; $\mathrm{H}, 7.74 ; \mathrm{N}, 15.37 \%$.

(2'S)-N-(2'-Methoxymethylpyrrolidine)-2-isocyanopropionamide 4 . To a stirred solution of the compound $3(1.82 \mathrm{~g}, 10 \mathrm{mmol})$ in dry THF $(20 \mathrm{ml})$ was added a solution of $n$-BuLi ( $10 \mathrm{mmol}, 15 \%$ in hexane) at $-78^{\circ} \mathrm{C}$. After the mixture had been stirred for $30 \mathrm{~min}$ at $-78^{\circ} \mathrm{C}$, a solution of methyl iodide $(1.42 \mathrm{~g}, 10 \mathrm{mmol})$ in dry THF $(5 \mathrm{ml})$ was added, and the reaction mixture was stirred for $2 \mathrm{hr}$ at $-78^{\circ} \mathrm{C}$ and then kept for $3 \mathrm{hr}$ at $0^{\circ} \mathrm{C}$. After removing the solvent, the residue was dissolved in
$\mathrm{CH}_{2} \mathrm{Cl}_{2}(50 \mathrm{ml})$, washed with water $(10 \mathrm{ml})$ and dried over $\mathrm{Na}_{2} \mathrm{SO}_{4}$. Evaporation of the solvent gave the crude product 4, which was purified by silica gel column chromatography (eluting with an increasing amount of AcOEt in benzene) to give $1.7 \mathrm{~g}$ of pure 4 as an oil $(85 \%$ yield). IR $v_{\max }^{\mathrm{KBr}} \mathrm{cm}^{-1}: 2140 \quad(\mathrm{~N}=\mathrm{C}:), 1650 \quad(\mathrm{C}=\mathrm{O})$. ${ }^{1} \mathrm{H}-\mathrm{NMR}\left(\mathrm{CDCl}_{3}\right) \delta: 1.33 \sim 1.52\left(3 \mathrm{H}, \mathrm{d}, J=8 \mathrm{~Hz}, \mathrm{CH}_{3}\right)$, $3.12\left(3 \mathrm{H}, \mathrm{s}, \mathrm{O}-\mathrm{CH}_{3}\right)$. Anal. Found: C, 61.09; H, 8.16; N, 14.20. Calcd. for $\mathrm{C}_{10} \mathrm{H}_{16} \mathrm{O}_{2} \mathrm{~N}_{2}: \mathrm{C}, 61.20 ; \mathrm{H}, 8.22 ; \mathrm{N}$, $14.28 \%$.

(2'S )- N-(2'-Hydroxymethylpyrrolidine)-2-isocyanopropionamide 5. To a solution of the methyl 2isocyanopropionate $\mathbf{2 b}(1 \mathrm{~g}, 8.8 \mathrm{mmol})$ in $\mathrm{MeOH}(5 \mathrm{ml})$ was added a solution of the prolinole $1 \mathrm{a}(2 \mathrm{~g}, 19.8 \mathrm{mmol})$ in $\mathrm{MeOH}(3 \mathrm{ml})$, the mixture being stirred for $2 \mathrm{hr}$ at ambient temperature.

After removing the solvent, the residue was purified by silica gel column chromatography (eluting with an increasing amount of AcOEt in benzene) to afford $\mathbf{5}$ as an oil $(1.5 \mathrm{~g}, 93 \%)$. IR $v_{\max }^{\mathrm{KBr}} \mathrm{cm}^{-1}: 3350(\mathrm{OH}), 2130(\mathrm{~N}=\mathrm{C}:), 1640$ $(\mathrm{C}=\mathrm{O}) .{ }^{1} \mathrm{H}-\mathrm{NMR}\left(\mathrm{CDCl}_{3}\right) \delta: 1.24 \sim 1.68(3 \mathrm{H}, \mathrm{d}, J=7 \mathrm{~Hz}$, $\mathrm{CH}_{3}$ ), $4.0 \sim 4.34$ (1H, br.s, $\left.\mathrm{OH}\right)$. Anal. Found: C, 59.35; H, 7.76; N, 15.32. Calcd. for $\mathrm{C}_{9} \mathrm{H}_{14} \mathrm{O}_{2} \mathrm{~N}_{2}: \mathrm{C}, 59.32 ; \mathrm{H}, 7.74$; $\mathrm{N}, 15.37 \%$.

\section{$\alpha$-Methylglutamic acid 7.}

Method A: A solution of $4(1.96 \mathrm{~g}, 10 \mathrm{mmol})$ in dry THF $(10 \mathrm{ml})$ was added to a stirred suspension of $\mathrm{NaH}(240 \mathrm{mg}$, $10 \mathrm{mmol})$ in dry THF $(50 \mathrm{ml})$, and the mixture was stirred for $10 \mathrm{~min}$ at $-78^{\circ} \mathrm{C}$. To the reaction mixture was added a solution of methyl acrylate $(1.03 \mathrm{~g}, 12 \mathrm{mmol})$ in dry THF $(10 \mathrm{ml})$, the mixture being stirred for $3 \mathrm{hr}$ at $-78^{\circ} \mathrm{C}$ and then kept for $3 \mathrm{hr}$ at between -30 and $-35^{\circ} \mathrm{C}$. The reaction mixture was then acidified with acetic acid $(5 \mathrm{ml})$ and the solvent evaporated in vacuo $\left(40 \sim 50^{\circ} \mathrm{C}\right)$ to afford the adduct 6 . This product was purified by silica gel column chromatography (eluting with an increasing amount of AcOEt in benzene) to give $2.1 \mathrm{~g}$ of pure 6 as a colorless oil $\left(70 \%\right.$ from 3). IR $v_{\max }^{\mathrm{KBr}} \mathrm{cm}^{-1}: 3300(\mathrm{NH}-$ $\mathrm{CHO}), 1760(\mathrm{C}=\mathrm{O}) .{ }^{1} \mathrm{H}-\mathrm{NMR} \delta: 1.75\left(3 \mathrm{H}, \mathrm{s}, \mathrm{CH}_{3}\right), 3.22$ $\left(3 \mathrm{H}, \mathrm{s}, \mathrm{O}-\mathrm{CH}_{3}\right), 3.56\left(3 \mathrm{H}, \mathrm{s}, \mathrm{O}-\mathrm{CH}_{3}\right)$. Anal. Found: C, 55.91; $\mathrm{H}, 8.11 ; \mathrm{N}, 9.28$. Calcd. for $\mathrm{C}_{14} \mathrm{H}_{24} \mathrm{O}_{5} \mathrm{~N}_{2}$ : C, 55.98; $\mathrm{H}, 8.05 ; \mathrm{N}, 9.32 \%$.

A solution of $6(1.06 \mathrm{~g}, 3.51 \mathrm{mmol})$ in $3 \mathrm{~N}-\mathrm{HCl}(30 \mathrm{ml})$ was heated for $10 \sim 12 \mathrm{hr}$ at $80 \sim 90^{\circ} \mathrm{C}$. After removing the generated amine by $\mathrm{CH}_{2} \mathrm{Cl}_{2}$ extraction, the aqueous phase was adjusted to pH 7 with $\mathrm{NaHCO}_{3}$ and applied to a Dowx $50 \times 8$ column $\left(\mathrm{H}^{+}\right.$form $)$. The column was washed with water, and then the $\alpha$-methylglutamic acid 7 was eluted with $5 \% \mathrm{NH}_{4} \mathrm{OH}$.

The eluted fraction was concentrated in vacuo and the residual oil was adjusted to $\mathrm{pH} 3$ with $0.5 \mathrm{~N}-\mathrm{HCl}$ to obtain 7. Recrystallization from $\mathrm{EtOH}$ gave 7 in its pure state (237 mg, $42 \%$ yield $), \mathrm{mp} 170^{\circ} \mathrm{C},[\alpha]_{\mathrm{D}}^{20}-1.22^{\circ}(c=1.31,6 \mathrm{~N}-$ $\mathrm{HCl})$. This product was identical with the authentic compound by TLC, IR and NMR analyses. 
Method B: A solution of $5(911.1 \mathrm{mg}, 5 \mathrm{mmol})$ in dry THF $(10 \mathrm{ml})$ was added to a stirred suspension of $\mathrm{NaH}$ $(120 \mathrm{mg}, 5 \mathrm{mmol})$ in dry THF $(30 \mathrm{ml})$, and the mixture was stirred for $10 \mathrm{~min}$ at $-78^{\circ} \mathrm{C}$. To the reaction mixture was added a solution of methyl acrylate $(686.7 \mathrm{mg}, 8 \mathrm{mmol})$ in dry THF $(10 \mathrm{ml})$, the mixture being stirred for $3 \mathrm{hr}$ at $-78^{\circ} \mathrm{C}$ and then kept for $3 \mathrm{hr}$ at between -30 and $-35^{\circ} \mathrm{C}$. The reaction mixture was acidified with acetic acid $(5 \mathrm{ml})$ and the solvent was evaporated in vacuo at $40 \sim 50^{\circ} \mathrm{C}$. The residue was dissolved in $\mathrm{CH}_{2} \mathrm{Cl}_{2}(70 \mathrm{ml})$, washed with water $(10 \mathrm{ml})$ and dried over $\mathrm{Na}_{2} \mathrm{SO}_{4}$. Evaporation of the solvent in vacuo afforded a mixture of the C-alkyl amide 8 and C,O-diakyl amide $9(1: 2)$, which were separated into the pure oily products $8(337 \mathrm{mg}, 27 \%$ yield) and $9(880 \mathrm{mg}, 53 \%$ yield) by silica gel column chromatography (eluting with an increasing amount of AcOEt in benzene).

Compound 8. IR $v_{\max }^{\mathrm{KBr}} \mathrm{cm}^{-1}: 3300(\mathrm{OH}), 1730(\mathrm{C}=\mathrm{O})$, $1660(\mathrm{C}=\mathrm{O}) .{ }^{1} \mathrm{H}-\mathrm{NMR}\left(\mathrm{CDCl}_{3}\right) \delta: 1.17\left(3 \mathrm{H}, \mathrm{s}, \mathrm{CH}_{3}\right), 3.68$ (3H, s, O- $\left.\mathrm{CH}_{3}\right), 8.1 \sim 8.15$ (1H, br.s, CHO). Anal. Found: C, 54.43; $\mathrm{H}, 7.76 ; \mathrm{N}, 9.66$. Calcd. for $\mathrm{C}_{13} \mathrm{H}_{22} \mathrm{O}_{5} \mathrm{~N}_{2}: \mathrm{C}$, $54.53 ; \mathrm{H}, 7.75 ; \mathrm{N}, 9.78 \%$.

Compound 9. IR $v_{\max }^{\mathrm{KBr}} \mathrm{cm}^{-1}: 1730(\mathrm{C}=\mathrm{O}), 1670(\mathrm{C}=\mathrm{O})$. ${ }^{1} \mathrm{H}-\mathrm{NMR}\left(\mathrm{CDCl}_{3}\right) \delta: 1.63\left(3 \mathrm{H}, \mathrm{s}, \mathrm{CH}_{3}\right), 3.6(6 \mathrm{H}, \mathrm{s}, \mathrm{O}-$ $\left.\mathrm{CH}_{3} \times 2\right), 8.0 \sim 8.15(1 \mathrm{H}, \mathrm{m}, \mathrm{CHO})$. Anal. Found: C, 54.76; $\mathrm{H}, 7.55 ; \mathrm{N}, 7.61$. Calcd. for $\mathrm{C}_{17} \mathrm{H}_{28} \mathrm{O}_{7} \mathrm{H}_{2}$ : C, 54.84; $\mathrm{H}$, $7.58 ; \mathrm{N}, 7.52 \%$.

According to the same procedure as that used for 6 , the amides 8 and $\mathbf{9}$ afforded $\mathbf{7 .}$

Compound 7 from 8 . Yield $66 \%$, mp $169 \sim 170^{\circ} \mathrm{C},[\alpha]_{\mathrm{D}}^{22}$ $-5.35^{\circ}(c=0.71,6 \mathrm{~N}-\mathrm{HCl})$.

Compound 7 from 9 . Yield $50 \%$, mp $169 \sim 172^{\circ} \mathrm{C}$. $[\alpha]_{\mathrm{D}}^{22}$ $+0.61^{\circ}(c=0.99,6 \mathrm{~N}-\mathrm{HCl})$.

These compounds 7 were identical with the sample obtained in Method $A$ in all respects except for the optical rotation.

\section{$\alpha$-Methylornthine $\mathbf{1 2}$.}

Michael-addition adduct 10. A solution of $4(1.9 \mathrm{~g}$, $9.7 \mathrm{mmol})$ in dry THF $(10 \mathrm{ml})$ was added to a stirred suspension of $\mathrm{NaH}(240 \mathrm{mg}, 10 \mathrm{mmol})$ in dry THF $(30 \mathrm{ml})$ at $-78^{\circ} \mathrm{C}$.

After the mixture had been stirred for $10 \mathrm{~min}$ at $-78^{\circ} \mathrm{C}$, a solution of acrylonitrile $(673 \mathrm{mg}, 12 \mathrm{mmol})$ in dry THF $(10 \mathrm{ml})$ was added, the resulting mixture being stirred for $3 \mathrm{hr}$ at $-78^{\circ} \mathrm{C}$ and then kept for $3 \mathrm{hr}$ at between -35 and $-30^{\circ} \mathrm{C}$. The reaction mixture was acidified with acetic acid $(5 \mathrm{ml})$ and the solvent was evaporated in vacuo $\left(40 \sim 50^{\circ} \mathrm{C}\right)$ to afford crude 10 . This product was purified by silica gel column chromatography (eluting with an increasing amount of AcOEt in benzene) to give $2.03 \mathrm{~g}$ of pure 10 as an oil $\left(76 \%\right.$ from 3). IR $v_{\max }^{\mathrm{KBr}} \mathrm{cm}^{-1}: 3250(\mathrm{NH}-$ $\mathrm{CHO}), 2250(\mathrm{CN}), 1670(\mathrm{C}=\mathrm{O}) .{ }^{1} \mathrm{H}-\mathrm{NMR}\left(\mathrm{CDCl}_{3}\right) \delta$ : $1.61\left(3 \mathrm{H}, \mathrm{d}, J=7 \mathrm{~Hz}, \mathrm{CH}_{3}\right), 2.30\left(3 \mathrm{H}, \mathrm{s}, \mathrm{CH}_{3}\right), 7.61(1 \mathrm{H}, \mathrm{s}$, $\mathrm{NH}), 8.16$ (1H, s, CHO). Anal. Found: C, 58.33; H, 7.96; $\mathrm{N}, 15.66$. Calcd. for $\mathrm{C}_{13} \mathrm{H}_{21} \mathrm{O}_{3} \mathrm{~N}_{3}$ : C, 58.41; H, 7.92; N, $15.72 \%$
$N$-Acetyl compound 11. A suspension of $\mathbf{1 0}(2.67 \mathrm{~g}$, $10 \mathrm{mmol})$ in acetic anhydride $(20 \mathrm{ml})$ was catalytically hydrogenated with Raney nickel (R-100, approx. 2 g) under $30 \sim 50 \mathrm{~kg} / \mathrm{cm}^{2}$ pressure at $50^{\circ} \mathrm{C}$ until four equivalents of hydrogen had been absorbed. After removing the solvent and catalyst, the residue was dissolved in $\mathrm{CH}_{2} \mathrm{Cl}_{2}$ $(100 \mathrm{ml})$, washed with water $(10 \mathrm{ml})$ and dried over $\mathrm{Na}_{2} \mathrm{SO}_{4}$. Evaporation of the solvent gave crude 11, which was purified by silica gel column chromatography (eluting with an increasing amount of AcOEt in benzene) to afford $1.9 \mathrm{~g}$ of pure 11 as an oil $\left(71 \%\right.$ yield). IR $v_{\max }^{\mathrm{KBr}} \mathrm{cm}^{-1}: 3270$ (NH-CHO), $1660 \quad(\mathrm{C}=\mathrm{O}), 1620 \quad(\mathrm{C}=\mathrm{O}) .{ }^{1} \mathrm{H}-\mathrm{NMR}$ $\left(\mathrm{CDCl}_{3}\right) \delta: 3.30\left(3 \mathrm{H}, \mathrm{s}, \mathrm{O}-\mathrm{CH}_{3}\right), 7.3(1 \mathrm{H}$, br.s, $\mathrm{NH}), 8.1$ (1H, s, CHO). Anal. Found: C, 57.40; H, 8.65; N, 13.35 . Calcd. for $\mathrm{C}_{15} \mathrm{H}_{27} \mathrm{O}_{4} \mathrm{~N}_{3}$ : C, 57.48; $\mathrm{H}, 8.68 ; \mathrm{N}, 13.41 \%$.

$\alpha$-Methylornithine 12. A mixture of $11(1.5 \mathrm{~g}, 4.79 \mathrm{mmol})$ and $6 \mathrm{~N}-\mathrm{HCl}(50 \mathrm{ml})$ was heated for $2 \mathrm{hr}$ at $90 \sim 100^{\circ} \mathrm{C}$ and then extracted with $\mathrm{CH}_{2} \mathrm{Cl}_{2}$ to remove the generated amine. The aqueous phase was adjusted to $\mathrm{pH} 7$ with $\mathrm{NaHCO}_{3}$ and applied to a column containing $15 \mathrm{~g}$ of cation $\left(\mathrm{H}^{+}\right)$exchange resin (Dowex $50 \times 8$ ).

The column was initially washed with water and then $\mathbf{1 2}$ was eluted with $5 \% \mathrm{NH}_{4} \mathrm{OH}$. The eluted fraction was concentrated under reduced pressure and the residue was adjusted to pH 5 with $0.5 \mathrm{~N}-\mathrm{HCl}$ to yield $12-\mathrm{HCl}(453 \mathrm{mg}$, $\left.51.9^{\circ}\right) \cdot[\alpha]_{\mathrm{D}}^{26}-3.33^{\circ}(c=1.05,5 \mathrm{~N}-\mathrm{HCl})$.

This product was identical with the sample reported previously in all respects. ${ }^{14)}$

Acknowledgments. The authors wish to thank Dr. G. Isagawa and H. Nakase of the Department of Applied Chemistry of this University for elemental analysis.

\section{REFERENCES}

1) M. Kirihata, S. Mihara, I. Ichimoto and H. Ueda, Agric. Biol. Chem., 42, 185 (1978).

2) M. Kirihata, Bull. Univ. Osaka Prefect., Ser. B, 33, 135 (1981).

3) P. Bey and J. P. Vevert, Tetrahedron Lett., 1455 (1977).

4) P. Bey, C. Danzin, •V. Van Dorsselaer, P. Mamont, M. Jung and C. Tardif, J. Med. Chem., 21, 50 (1977).

5) C. G. Unson and B. W. Erickson, Int. J. Pept. Protein Res., 22, 50 (1983).

6) G. Otani and S-I. Yamada, Chem. Pharm. Bull., 21, 2112 (1973).

7) M. Kolb and J. Barth, Tetrahedron Lett., 2999 (1979)

8) K. G. Davenport, H. Eichenauer, D. Enders, M. Newcomb and D. E. Bergbreiter, J. Am. Chem. Soc., 101, 2654 (1979).

9) D. Enders and H. Eichenauer, Angew. Chem. Int. Ed. Engl., 18, 397 (1979).

10) H. Ahlbrecht, G. Bonnet, D. Enders and G. Zimmermann, Tetrahedron Lett., 21, 3175 (1980).

11) K. Achiwa and S-I. Yamada, Tetrahedron Lett., 20, 
1799 (1974).

12) P. E. Sonnet and R. R. Heath, J. Org. Chem., 45, 14) The authentic DL- $\alpha$-methylornithine is available from 3137 (1980).

13) P. E. Sonnet and R. R. Heath, J. Chem. Ecol., 8, 41 